\title{
COMUNICAÇÃO
}

\section{O REAL SIGNIFICADO DE EXAMES SOROLÓGICOS NO DIAGNÓSTICO DE DOENÇAS ENDÊMICAS}

\author{
Antonio R.L. Teixeira e Ana de Cássia Vexenat
}

\begin{abstract}
Clínicos e epidemiologistas sempre pedem exames sorológicos para confirmar o diagnóstico e esperam que os resultados sejam confiáveis. Especificidade e sensibilidade são qualidades essenciais que repercutem no resultado e na expectativa do pedido. Em alguns casos, porém, os exames podem gerar informaçōes que nem sempre são compatíveis com o diagnóstico. Vários métodos têm sido empregados para esclarecer as dúvidas levantadas pelas reações cruzadas dos anticorpos séricos de portadores de doenças crônicas endêmicas. Os estudos mostram que é praticamente impossível definir, em base esritamente sorológica, o agente de infecçâo clínica silenciosa causada por Trypanosoma cruzi, Leisbmania braziliensis, Leishmania chagasi e, também, esquistossomose, malária, hanseníase, sífilis, tuberculose, pênfigo e paracoccidioidose. A análise pelo Western blot mostra que anticorpos nesses soros identificam diversas bandas de proteínas nos antígenos heterólogos. Essas bandas sugerem a presença de determinantes antigênicos comuns e explicam as reações sorológicas cruzadas.
\end{abstract}

As infecções humanas por protozoários da ordem Kinetoplastida e por outros agentes de doenças endêmicas podem ser diagnosticadas por exames laboratoriais que permitem a demonstração direta do agente causal. Todavia, existe um grande número de infecções crônicas, silenciosas ou não, nas quais a demonstração parasitológica ou microbiológica é difícil de ser obtida. Nesses casos, um exame sorológico específico serviria de indício valioso da presença do agente causal. No sentido de testar a acuracidade dos exames ELISA, hemaglutinação indireta (HI) e imunofluorescência (IF) foram examinados soros de portadores de

\footnotetext{
Laboratório Multidisciplinar de Pesquisa em Doença de Chagas, Faculdade de Ciências da Saúde da Universidade de Brasilia, Brasilia, DF.

Endereço para correspondência: Dr. Antonio R.L. Teixeira Caixa Postal 04-685, 70919-970 Brasília, DF Fax: (061) 273-4645.

Recebido para pubicação em 03/08/95.
}

várias infecções crônicas com antígenos de $T$. cruzi, L. braziliensis e L. chagasi.

Os exames ELISA, HI e IF mostraram títulos de anticorpos em soros de pacientes portadores de doença de Chagas, acima dos soros controles, quando o antígeno de $T$. cruzi foi empregado ${ }^{6}$. Entretanto, todos soros de calazar e $55 \%$ dos portadores de leishmaniose cutâneo-mucosa também apresentavam sorologia positiva com o antígeno de T. cruzi. A despeito de que todos os soros de calazar tinham sorologia positiva com o antígeno homólogo, o ELISA também mostrou $100 \%$ de positividade com soro de leishmaniose cutâneo-mucosa e com 98\% dos soros chagásicos, quando o antígeno de $L$. chagasi foi empregado. Similarmente, os soros de portadores de leishmaniose cutâneo-mucosa foram positivos com o antígeno homólogo, mas todos soros de portadores de Chagas e de calazar também tinham títulos elevados de anticorpos demonstrados nos exames ELISA e IF contra antígeno de L. braziliensis.

A ocorrência de reações cruzadas com os antígenos de T. cruzi, L. braziliensis e $L$. chagasi foi estudada em portadores de doenças endêmicas ${ }^{6}$. Assim, $62 \%$ dos casos de pênfigo, $60 \%$ dos maláricos e sifilíticos, $50 \%$ de esquistosomose e de hanseníase, e $20 \%$ dos casos de tuberculose e de paracoccidioidose foram positivos pelo teste ELISA. Entretanto, o maior percentual de reaçôes cruzadas no teste HI foi observado em soros de tuberculosos e de esquistossomóticos.

A análise pelo Western blot mostrou que os soros de chagásicos que formaram pelo menos 24 bandas com o antígeno de T. cruzi também formaram 13 bandas com L. chagasi e 17 bandas com antígeno de $L$. braziliensis ${ }^{6}$. Os soros de calazar que reconheceram pelo menos 29 bandas com o antígeno homólogo também formaram 14 bandas com o antígeno de T. cruzi e 10 bandas com L. braziliensis. Os soros de leishmaniose cutâneo-mucosa que formaram pelo menos 17 bandas com o antígeno homólogo também formaram 10 
bandas com $T$. cruzi e quatro bandas com $L$. braziliensis.

Finalmente, a análise dos antígenos dos protozoários com soros de portadores de seis doenças endêmicas mostrou diversas bandas de proteínas na faixa de 210 a $8 \mathrm{kDA}$. O antígeno de $T$. cruzi formou bandas identificadas por anticorpos nos soros de portadores de tuberculose, paracoccidioidomicose e hanseníase. $L$. braziliensis contém proteínas antigênicas que reagem cruzadamente com anticorpos de portadores de tuberculose, hanseníase, esquistossomose, pênfigo e paracoccidioidose. Por sua vez, o antígeno de L. chagasi mostrou diversas proteínas que reagem cruzadamente com anticorpos nos soros de portadores dessas infecções ${ }^{6}$.

$\mathrm{Na}$ tentativa de esclarecer o diagnóstico sorológico de calazar fez-se a reação de aglutinação direta (AD) com formas mortas de L. chagasi. Observou-se que todos os soros de calazar e $80 \%$ dos soros de leishmaniose cutâneo-mucosa tinham títulos de anticorpos acima de 1:1600'. Todavia, os soros chagásicos e controles deram resultados negativos (títulos abaixo de $1: 1600$ ). No conjunto, esses resultados mostram que é impossível fazer o diagnóstico sorológico diferencial preciso entre leishmaniose cutâneo-mucosa e calazar, mas é possivel separar aqueles casos dos chagásicos.

Entre soros controles de indivíduos sem indícios da presença de qualquer das doenças acima, observaram-se dois resultados positivos com antígeno de L. braziliensis e sete com antígeno de $L$. chagasi, pelos testes ELISA e HI. No conjunto, o grande número de resultados positivos reflete a alta sensibilidade e baixa especificidade dos testes empregados. Enfim, determinantes antigênicos comuns explicam as reações cruzadas identificadas pelos exames imunológicos.

A grande quantidade de métodos e técnicas empregados nos exames sorológicos parece ser uma indicação da dificuldade de obtenção de resultados que permitam subsidiar diagnósticos clínicos com absoluta acuracidade. Essa finalidade poderia ser preenchida apenas por método altamente específico e sensivel, mas que inexiste. A especificidade de um exame imunológico está relacionada a sua acuracidade e reproducibilidade, coincidente com a demonstração direta do agente infeccioso. A sensibilidade diz respeito a sua capacidade de indicar o maior número de portadores da infecção na ausência de demonstração do agente infeccioso pela cultura e exame microscópico. O grande desafio reside naqueles pacientes em que o agente causal não foi demonstrado previamente. Nesses casos a utilização de método imunológico de alta sensibilidade e especificidade tem seu real valor.

Evidentemente, nem sempre é possivel trabalhar com técnicas que oferecam total especificidade e sensibilidade. O método imunológico mais sensível geralmente é menos específico. A alta sensibilidade de um método depende dos determinantes antigênicos (número de epítopos) contra os quais se formam os anticorpos séricos. Por outro lado, a especificidade depende da existência exclusiva dos epítopos no agente infeccioso que se quer diagnosticar. A medida que hajam epítopos semelhantes em outros microorganismos, ou mesmo em tecidos do hospedeiro, haverá possibilidade de resultados falso-positivos que indicam baixa especificidade e alta sensibilidade do método empregado. Em situação oposta, o método de baixa sensibilidade deixará de diagnosticar casos em que o limite de detecção da reação antígenoanticorpo situa-se abaixo de seu limiar de revelação. Nesse caso, haverá possibilidade de resultado falso-negativo, indicando a pouca sensibilidade do método usado. Nenhuma dessas situações deve passar despercebida, quando se trata de subsidiar o diagnóstico clínico-epidemiológico, pois elas se ajustam ao conhecimento básico da imunologia.

Guimarães $^{2}$ definiu sensibilidade como sendo a capacidade de um teste discriminar, dentre os suspeitos de uma patologia, aqueles efetivamente doentes. Sua definição de especificidade era tida como a capacidade que o mesmo teste teria de ser negativo em amostragem de indivíduos que sabidamente não têm a doença. Ou então, como foi colocado por Galen e $\mathrm{col}^{1}$, sensibilidade seria "positividade na doença" e especificidade seria "negatividade na saúde". Evidentemente, esses autores limitaram suas definições à questão doença $v s$ saúde, e não se preocuparam com o fato de que os testes sorológicos também diagnosticam os casos de infecção sem doença manifesta.

Nosso conceito de especificidade e sensibilidade difere daquele de Galen e coll $^{1}$. 
Comunicação. Teixeira ARL, Vexenat AC. O real significado de exames sorológicos no diagnóstico de doenças endêmicas. Revista da Sociedade Brasileira de Medicina Tropical 29:379-382, jul-ago, 1996.

Nós consideramos que especificidade é a capacidade do teste sorológico diagnosticar todos os casos de determinada infecção em uma amostragem que teve o agente etiológico demonstrado. Quanto mais específico for o teste, menor será o número de resultados falsos. Por outro lado, consideramos sensibilidade a capacidade do teste sorológico diagnosticar um número máximo de exames positivos em uma amostragem, sem que seja possível demonstrar o agente etiológico em todos os casos. Quanto mais sensivel for o teste, maior será o número de casos falsopositivos. Ou seja, o teste mais sensivel será necessariamente menos específico, e viceversa. Conseqüentemente, as reações cruzadas indicam alta sensibilidade e baixa especificidade de um teste sorológico.

$\mathrm{Na}$ tentativa de resolver as dificuldades associadas com especificidade e sensibilidade de testes sorológicos, tem-se procurado utilizar antígenos recombinantes no diagnóstico de doenças endêmicas. Assim, diversos antígenos recombinantes têm sido isolados de genotecas de expressão de microorganismos, através de seleção com soros de pacientes portadores da infecção específica. Sua utilização tem mostrado que muitos desses antígenos apresentam grande especificidade, mas sabese que eles podem produzir resultados falsonegativos, devido ao fato de possuírem um número limitado de epítopos. Por essa razão, prevê-se que melhores resultados poderiam ser obtidos com misturas de antígenos recombinantes, tendo em vista a posssibilidade de torná-los mais sensíveis's. Daí a expectativa na padronização do ELISA com mistura de antígenos recombinantes, pois no futuro poderá substituir os extratos antigênicos naturais empregados no diagnóstico da doença de Chagas e outras doenças endêmicas. A vantagem de tal substituição teria de ser demonstrada.

A técnica de PCR (reação de polimerização em cadeia) também gerou a expectativa de solução para o diagnóstico diferencial das doenças produzidas por protozoários da ordem Kinetoplastida e, entre essas e diversas doenças crônicas que reconhecidamente produzem reações cruzadas com antígenos daqueles protozoários. Parece que a alta sensibilidade dessa técnica tem sido uma desvantagem, pois a especificidade dos resultados ficaria prejudicada e, pelo menos até esse momento, ainda não foi adotada como um método de rotina para diagnóstico laboratorial dessas infecções.

Na Reunião de Pesquisa Aplicada em Doença de Chagas, em Uberaba, ShikanaiYasuda e cols ${ }^{-}$mostraram resultados de pesquisa que recomendam a técnica de PCR como meio de potenciação da sensibilidade do xenodiagnóstico. Utilizando 54 grupos pareados de 10 Triatoma infestans alimentados em 19 pacientes chagásicos em três diferentes ocasiões, os autores extraíram DNA das amostras coletadas e procederam a PCR com um par de oligonucleotídeos TCZ1 e TCZ2. Esses oligos amplificam uma seqüência de 188 pares de base do DNA genômico do T. cruzỉ . Verificaram que $90 \%$ dos pacientes tiveram amostras positivas em pelo menos um grupo de insetos, enquanto em apenas $26 \%$ desses casos houve positividade pela leitura microscópica. A especificidade teria sido demonstrada nos 15 grupos de insetos alimentados em 5 pacientes com pelo menos uma leitura microscópica positiva, nos quais a PCR mostrou resultado positivo em todos eles. Aguarda-se o resultado de estudo duplo-cego em população de área endêmica, pois tais resultados indicariam a importância da PCR na avaliação pós-terapêutica ou mesmo diagnóstica, em casos com reaçôes sorológicas inconclusivas.

\section{REFERÊNCIAS BIBLIOGRÁFICAS}

1. Galen RS, Gambino SR. The predictive value and efficiency of medical diagnosis. J. Willey \& Sons, New York, 1975.

2. Guimarães MCS. Exames de laboratório: Sensibilidade, especificidade, valor preditivo positivo. Revista da Sociedade Brasileira de Medicina Tropical 18: 117-120, 1985.

3. Moser DDR, Kirchhoff LV, Donelson JE. Detection of Trypanosoma cruzi by polymerase chain reaction gene amplification. Journal of Clinical Microbiology 27: 1744-1749, 1989.

4. Shikanai-Yasuda MA, Ochs DE, Tolezana JE, Kirchhoff LV. Emprego de PCR para detecção de Trypanosoma cruzi em triatomíneos alimentados em pacientes com doença de Chagas crônica: comparação entre 2 diferentes métodos de extração. Revista da Sociedade Brasileira de Medicina Tropical 26(supl II): 94, 1993.

5. Silveira JE Aplicação de antígenos recombinantes de Trypanosoma cruzi no sorodiagnóstico da 
Comunicação. Teixeira ARL, Vexenat AC. O real significado de exames sorológicos no diagnóstico de doenças endêmicas. Revista da Sociedade Brasileira de Medicina Tropical 29:379-382, jul-ago, 1996.

doença de Chagas. Revista da Sociedade Brasileira de Medicina Tropical 26(supl II):11, 1993.

6. Vexenat ACOR. Diagnóstico sorológico diferencial de infecções causadas por Trypanosoma cruzi,
Leisbmania (Viannia) braziliensis, Leishmania chagasi e outras doenças crônicas. Dissertação de Mestrado, Universidade de Brasília, 1993. 